\title{
ORIENTASI TUJUAN MENYUSUN SKRIPSI DAN KECEMASAN DALAM MENULIS SKRIPSI
}

\author{
Deasyanti* \\ Marwa Nuruzdah** \\ *Fakultas Pendidikan Psikologi, Universitas Negeri Jakarta \\ **Fakultas Pendidikan Psikologi, Universitas Negeri Jakarta
}

DOI: https://doi.org/10.21009/JPPP.062.07

Alamat Korespondensi:

deasyanti@unj.ac.id

\begin{abstract}
The purpose of this study is to find out the relationship between thesis writing orientation and anxiety in thesis writing. Quantitative method is used in this study with 247 Universitas Negeri Jakarta students who is writing thesis as a samples. Sampling method used in this study is incidental sampling. The Instruments used in this study are adapted from Achievement Questionare Scale (Elliot \& McGregor, 2001) and Writing Apprehension Test (Daly \& Miller, 1975). Data analyzing method used in this study is pearson product moment. The goal orientations which is found negatively correlated with writing anxiety are mastery approach goal orientation ($0,31)$ and performance approach goal orientation $(-0,18)$. The goal orientation which is found positively correlated with writing anxiety are mastery avoidance goal orientation $(0,19)$ and performance avoidance $(0,26)$.
\end{abstract}

Keywords

goal orientation, achievement goal, writing apprehension, writing anxiety

\section{Pendahuluan}

Pendidikan Tinggi adalah institusi pendidikan untuk siswa yang ingin melanjutkan pendidikan setelah Sekolah Menengah Atas. Tujuan Pendidikan Tinggi yang diatur dalam UU RI No. 12 tahun 2012 pasal 5 adalah untuk terwujudnya pengabdian kepada masyarakat berbasis penalaran dan karya penelitian yang bermanfaat dalam memajukan kesejahteraan umum dan mencerdaskan kehidupan bangsa.

Salah satu rumusan keterampilan umum yang harus dimiliki di Pendidikan Tinggi adalah keterampilan dalam pembuatan laporan tertulis dan penyusunan hasil kajian penelitian. Pada proses pembuatan laporan tertulis, selain harus melakukan penelitian, para mahasiswa juga harus membuat hasil kajian tersebut dengan proses penulisan. Proses penulisan harus melalui proses menulis yang mencakup sub-proses berupa perenca- naan, pengumpulan data, pembuatan konsep, perevisian, penulisan kembali dan pengeditan. Sub-proses tersebut bersifat dinamis, tidak berurutan, dan saling interaktif (Ayodele \& Akinlana, 2012).

Tugas penulisan merupakan hal yang penting bagi mahasiswa, namun demikian tugas menulis bukan merupakan hal yang mudah bagi setiap orang. Terutama untuk mahasiswa dengan program sarjana, di mana mereka belum memiliki pengalaman menyusun skripsi sebelumnya. Berbeda dengan mahasiswa dengan jenjang magister dan doktoral yang sudah pernah merasakan pembuatan laporan tertulis dan penyusunan hasil kajian penelitian seperti skripsi.

Untuk melihat kesulitan apa yang ditemukan pada mahasiswa saat menulis skripsi, maka dilakukan studi pendahuluan berupa wawancara singkat terhadap mahasiswa yang sedang menger- 
jakan skripsi, di mana pada saat menulis skripsi mahasiswa harus berkecimpung dengan proses penulisan kurang lebih selama satu semester atau enam bulan. Hasil dari studi pendahuluan membuktikan bahwa 5 dari 10 mahasiswa mengalami kendala pada proses menulis skripsi. Kendala tersebut diantaranya adalah merasa cemas dan takut saat tulisannya dievaluasi dosen pembimbing, mereka juga merasa takut bahwa hasil tulisannya akan dianggap buruk oleh dosen pembimbing, dosen penguji saat sidang nanti, bahkan oleh diri mereka sendiri dan pembaca lain. Ada juga mahasiswa yang takut tidak lulus tepat waktu karena takut gagal dalam menulis skripsi.

Dari hasil studi pendahuluan tersebut maka ditemukan bahwa beberapa mahasiswa mengalami kecemasan dalam menulis skripsi. Sebagaimana yang dijelaskan oleh Daly \& Miller (1975) bahwa individu yang mengalami kecemasan dalam menulis adalah individu yang memiliki rasa takut saat hasil tulisannya dievaluasi, menghindari tugas penulisan dan jika situasi mengharuskan untuk mengerjakannya maka akan menghasilkan kecemasan, serta menganggap akan gagal saat menulis.

Mahasiswa yang memiliki kecemasan dalam menulis skripsi adalah mahasiswa yang takut hasil tulisan pada skripsinya dievaluasi, merasa cemas saat mengerjakan tugas penulisan skripsi seperti pikiran mereka kosong saat menulis skripsi, merasa tidak bisa dan kesulitan menuliskan ideide dan pemikirannya dengan jelas di skripsinya. Mahasiswa tersebut juga memiliki anggapan bahwa dia akan gagal saat membuat tulisan seperti merasa kemampuan menulisnya di bawah rata-rata, merasa tidak pandai dalam menulis, dan memperkirakan akan mendapatkan nilai skripsi yang buruk. Setelah melakukan wawancara lebih lanjut untuk memperdalam studi pendahuluan, beberapa mahasiswa mengalami kecemasan dalam menulis skripsi.

Menurut Kaywell, Johnston, \& Markle (1991) Individu yang memiliki kecemasan dalam menulis biasanya disebabkan oleh beberapa faktor, yakni masa lalu yang kurang berhasil dalam menulis (Daly \& Miller, 1975), umpan balik negatif (Gee, 1972), prokrastinasi (Cope, 1978), ketidakmampuan mengolah bahan bacaan (Cope, 1978), dan pengajar yang kritis (Emig, 1971).
Pada dasarnya setiap individu memiliki orientasi tujuan dalam mengerjakan tugas. Orientasi Tujuan adalah tujuan dari keterlibatan tugas (Maehr, 1989 dalam Elliot \& Church 1997). Individu yang terlibat dalam suatu tugas memiliki tujuan untuk apa mereka mengerjakan tugas tersebut. Menurut Elliot \& McGregor (2001) terdapat empat jenis orientasi tujuan dalam mengerjakan tugas, yakni mastery approach, mastery avoidance, performance approach, dan performance avoidance.

Mastery approach adalah individu yang ingin mendekati keberhasilan secara intrapersonal dalam mengerjakan tugas, sedangkan mastery avoidance adalah individu yang ingin menghindari kegagalan secara intrapersonal (Elliot \& McGregor, 2001). Intrapersonal yang dimaksud pada mastery adalah mendekati keberhasilan atau menghindari kegagalan yang diukur individu mengenai diri individu tersebut.

Jenis orientasi yang ketiga adalah performance approach, yakni individu yang ingin mendekati keberhasilan secara normatif, dan yang terakhir adalah performance avoidance di mana individu tersebut ingin menghindari kegagalan secara normatif (Elliot \& McGregor, 2001). Normatif yang dimaksud pada orientasi tujuan performance adalah mendekati keberhasilan atau menghindari kegagalan yang diukur individu menggunakan standar pencapaian orang lain.

Orientasi tujuan avoidance memiliki stimulus negatif untuk memberikan energi pada individu untuk menghindari kegagalan. Dengan demikian, individu yang memiliki orientasi tujuan avoidance baik berupa mastery dan performane mengakibatkan kecemasan karena menganggap dirinya akan gagal (Elliot \& McGregor, 2001). Berbeda dengan individu yang memiliki orientasi tujuan approach baik berupa mastery dan performance yang memiliki stimulus positif sebagai energi untuk berjuang memperoleh keberhasilan dan kesuksesan.

Terdapat hasil penelitian pada murid kelas 5 dan 6 yang dilakukan oleh Sideridis (2005) yang membuktikan bahwa orientasi tujuan performance avoidance berhubungan dengan tingginya kecemasan dan depresi, hal ini disebabkan karena mereka memiliki kecemasan yang tinggi untuk melindungi harga diri mereka. Mastery orien- 
tation memiliki hubungan negatif dengan kecemasan dan depresi.

Stan \& Oprea (2014) juga melakukan penelitian mengenai kecemasan dan orientasi tujuan. Berbeda dengan penelitian yang dilakukan Sideridis yang meneliti tentang kecemasan, penelitian yang dilakukan oleh Stan \& Oprea (2014) meneliti tentang kecemasan dalam ujian. Penelitian tersebut mendapatkan hasil yang sama dengan hasil penelitian Sideridis (2005) bahwa mastery orientation memiliki hubungan negatif dengan kecemasan dalam ujian, sedangkan performance avoidance memiliki hubungan positif dengan kecemasan dalam ujian. Menurut Zweig \& Webster (2004, dalam Stan \& Oprea, 2014) hal ini disebabkan karena individu yang memiliki orientasi tujuan mastery orientation memiliki emosi yang stabil, sedangkan individu yang memiliki orientasi tujuan performance avoidance fokus terhadap kemungkinan akan gagal dan menghindari ketidakmampuan sehingga menurut Stan \& Oprea (2014) hal tersebut dapat menunjukan kecemasan.

Kecemasan yang dilakukan oleh beberapa penelitian tersebut berupa kecemasan dan kecemasan dalam ujian. Lalu bagaimana dengan kecemasan dalam menulis yang dialami oleh mahasiswa yang sedang mengerjakan skripsi? Apakah terdapat hubungan antara orientasi tujuan yang dimiliki mahasiswa dalam menyusun skripsi dengan kecemasan dalam menulis skripsi?

\section{Metode Penelitian}

Tipe penelitian ini menggunakan kuantitatif melalui metode survey. Subjek penelitian ini memiliki karakteristik mahasiswa yang sedang mengerjakan skripsi di Universitas Negeri Jakarta.

Teknik pengumpulan data yang digunakan menggunakan incidental sampling dengan jumlah sampel yang didapatkan 247 mahasiswa. Variabel dalam penelitian ini diukur menggunakan skala yang diadaptasi dari Achievement Questionare Scale (Elliot \& McGregor, 2001) dan Writing Apprehension Test (Daly \& Miller, 1975).

\section{Hasil Penelitian dan Diskusi}

Data yang telah didapat diolah menggunakan z-score untuk mengklasifikasikan orientasi tujuan mahasiswa dalam mennyusun skripsi. Setelah terklasifikasi, data kembali diolah menggunakan perason product moment untuk melihat hubungannya dengan kecemasan dalam menulis skripsi.

Tabel 1. Klasifikasi Orientasi Tujuan

\begin{tabular}{ccc}
\hline Orientasi Tujuan & Frekuensi & Persentase \\
\hline Mastery Approach & 45 & $18 \%$ \\
\hline Mastery Avoidance & 64 & $26 \%$ \\
\hline Performance Approach & 74 & $30 \%$ \\
\hline Performance Avoidance & 64 & $26 \%$ \\
\hline Total & 247 & $100 \%$ \\
\hline
\end{tabular}

Tabel 2. Klasifikasi Kecemasan dalam Menulis

\begin{tabular}{ccc}
\hline Kelompok Skor & Jumlah & Persentase \\
\hline Tinggi & 120 & $47 \%$ \\
\hline Rendah & 127 & $53 \%$ \\
\hline Total & 247 & $100 \%$ \\
\hline
\end{tabular}

Tabel 3. Hasil Uji Korelasi

\begin{tabular}{ccc}
\hline Orientasi Tujuan & Kecemasan Menulis & Ket \\
\hline Mastery Approach & $-0,31$ & Signifikan \\
\hline Mastery Avoidance & 0,19 & Signifikan \\
\hline Performance Approach & $-0,18$ & Signifikan \\
\hline Performance Avoidance & 0,26 & Signifikan \\
\hline
\end{tabular}


Berdasarkan hasil korelasi antara keempat orientasi tujuan menyusun skripsi dan kecemasan dalam menulis skripsi, orientasi tujuan mastery approach dan performance approach berhubungan negatif secara signifikan, sedangkan orientasi tujuan mastery avoidance dan performance approach berhubungan positif secara signifikan. Mastery approach memiliki koefisien korelasi yang lebih tinggi daripada performance approach. Performance avoidance memiliki koefisien korelasi yang lebih tinggi daripada mastery avoidance.

Semakin tinggi mastery approach yang dimiliki mahasiswa dalam menyusun skrispi maka semakin rendah kecemasan dalam menulisnya. Semakin rendah mastery approach yang dimiliki mahasiswa dalam menyusun skripsi maka semakin tinggi kecemasan dalam menulisnya. Individu yang ingin menguasai skripsinya dengan baik, ingin mempelajari banyak sumber bacaan untuk skripsinya dan ingin memahami skripsinya sedetil mungkin akan memiliki kecemasan menulis yang rendah. Individu tersebut tidak merasa takut saat hasil tulisannya dievaluasi, senantiasa menganggap bahwa menulis skripsi merupakan hal yang menyenangkan, dan percaya bahwa dirinya mampu menulis skripsi serta akan menghasilkan skripsi yang baik.

Semakin tinggi mastery avoidance yang dimiliki mahasiswa dalam menyusun skrispi maka semakin tinggi pula kecemasan dalam menulisnya. Semakin rendah mastery avoidance yang dimiliki mahasiswa dalam menyusun skripsi maka semakin rendah pula kecemasan dalam menulisnya. Individu yang menghindari kegagalan dalam menulis skripsi dan merasa takut tidak menguasai skripsinya dengan baik akan merasa cemas dalam menulis skripsi. Individu tersebut akan merasa takut menulis skripsi karena takut skripsinya akan dievaluasi, memperkirakan akan gagal dalam menulis skripsi, dan merasa pikirannya kosong saat menulis skripsi.

Semakin tinggi performance approach yang dimiliki mahasiswa dalam menyusun skrispi maka semakin rendah kecemasan dalam menulisnya. Semakin rendah performance approach yang dimiliki mahasiswa dalam menyusun skripsi maka semakin tinggi kecemasan dalam menulisnya. Individu yang ingin berusaha untuk membuat skripsi yang lebih baik dari mahasiswa lainnya akan memiliki kecemasan menulis yang rendah. Individu tersebut tidak merasa takut saat hasil tulisannya dievaluasi, senantiasa menganggap bahwa menulis skripsi itu merupakan hal yang menyenangkan, dan percaya bahwa dirinya mampu menulis skripsi serta akan menghasilkan skripsi yang baik.

Semakin tinggi performance avoidance yang dimiliki mahasiswa dalam menyusun skrispi maka semakin tinggi pula kecemasan dalam menulisnya. Semakin rendah performance avoidance yang dimiliki mahasiswa dalam menyusun skripsi maka semakin rendah pula kecemasan dalam menulisnya. Individu yang menghindari nilai skripsi yang buruk dibanding mahasiswa lainnya, serta memiliki motivasi dari ketakutan lulus lebih lama dibanding mahasiswa lainnya akan merasa cemas dalam menulis skripsi. Individu tersebut akan merasa takut menulis skripsi karena takut skripsinya akan dievaluasi, memperkirakan akan gagal dalam menulis skripsi, dan merasa pikirannya kosong saat menulis skripsi.

Hasil dari penelitian ini sesuai dengan hasil penelitian Sideridis (2005) dan Stan \& Oprea (2014). Hasil penelitian Sideridis (2005) menemukan bahwa orientasi tujuan mastery dan performance approach berhubungan negatif dengan kecemasan dan depresi, sedangkan orientasi tujuan performance avoidance berhubungan positif dengan kecemasan dan depresi. Hasil penelitian Stan \& Oprea (2014) menemukan bahwa orientasi tujuan mastery dan performance approach berhubungan negatif dengan kecemasan dalam ujian, sedangkan orientasi tujuan performance avoidance berhubungan positif dengan kecemasan dalam ujian. Hasil dari penelitian ini membuktikan bahwa orientasi tujuan tidak hanya berhubungan dengan kecemasan dalam ujian serta kecemasan dan depresi saja. Orientasi tujuan juga berhubungan dengan kecemasan dalam menulis sebagaimana dari hasil yang didapatkan dalam penelitian ini.

\section{Kesimpulan}

Kesimpulan dari penelitian ini adalah berdasarkan uji hipotesis yang telah dilakukan dapat dilihat bahwa terdapat hubungan antara orientasi tujuan menyusun skripsi dengan kecemasan dalam menulis skripsi. Orientasi tujuan mastery approach dan performance approach memiliki 
hubungan negatif signifikan dengan kecemasan dalam menulis skripsi, sedangkan mastery avoidance dan performance avoidance memiliki hubungan positif signifikan dengan kecemasan dalam menulis skripsi.

Penelitian ini juga menemukan bahwa pada mahasiswa UNJ paling banyak yang memiliki orientasi tujuan performance approach dan paling sedikit yang memiliki orientasi tujuan mastery approach. Mahasiswa UNJ juga lebih banyak yang memiliki kecemasan dalam menulis kategori rendah daripada kecemasan dalam menulis kategori tinggi.

\section{Daftar Pustaka}

Ayodele, K. O., \& Akinlana, T. (2012). Writing Apprehension and Nigerian Undergraduates' Interest in Dissertation's Writing: The Moderator Effect of SelfEfficacy, Emotional Intelligence and Academic Optimism. The African Symposium, 12(1), 46-56.

Daly, J. A., \& Miller, M. D. (1975). The Empirical of An Instrument to Measure Writing Apprehension. Research in The Teaching of English, 9(3), 242-249.

Elliot, A. J., \& McGregor, H. A. (2001) A 2 X 2 Achievement Goal Framework. Journal of Personality and Social Psychology, 80(3), 501-519.

Elliot, A. J. (2005). A Conceptual History of the Achievement Goal Construct. In A. J. Elliot ve C.S. Dweck (Ed.), Handbook of Competence and Motivation. New York, USA: The Guilford Press.
Kara, S. (2013). Writing Anxiety: A Case Study on Students' Reasons for Anxiety in Writing Classes. Anadolu Journal of Educational Sciences International, 3(1), 103-111.

Kaywel, J. F., Johnston, J. H., Markle, G. C. (1991). What Researcher Says to The Practioner: Writing Apprehension. Middle School Journal, 22(4), 52-56.

Negari, G. M., \& Rezaabadi, O. T. (2012). Too Nervous to Write? The Relationship Between Anxiety and EFL Writing. Theory and Practice in Language Studies, 2(12), 2578-2586.

Riset dan Pengembangan, Kementrian Riset dan Teknologi Pendidikan Tinggi. (2012) Undang-Undang Republik Indonesia No 12. Retreived From http://www.risbang.risetdikti.go.id/regulas i/uu-12-2012.pdf\&ved.

Sideridis, G. D. (2005) Goal Orientation, Academic Achievement, and Depression: Evidence Favor of a Revised Goal Theory Framework. Journal of Educational Psychology, 97(3), 366-375.

Stan, A., \& Oprea, C. (2015). Test Anxiety and Achievement Goal Orientation of Students at a Romania University. Procedia Social and Behavioral Science, 180, 16731679. 